\title{
Barriers to effective management of type 2 diabetes in primary care:
}

\author{
qualitative systematic review
}

\begin{abstract}
Background

Despite the availability of evidence-based guidance, many patients with type 2 diabetes do not achieve treatment goals.

\section{Aim}

To guide quality improvement strategies for type 2 diabetes by synthesising qualitative evidence on primary care physicians' and nurses' perceived influences on care.
\end{abstract}

\section{Design and setting}

Systematic review of qualitative studies with findings organised using the Theoretical

Domains Framework.

\section{Method}

Databases searched were MEDLINE, Embase, CINAHL, Psyclnfo, and ASSIA from 1980 until March 2014. Studies included were Englishlanguage qualitative studies in primary care of physicians' or nurses' perceived influences on treatment goals for type 2 diabetes.

\section{Results}

A total of 32 studies were included: 17 address general diabetes care, 11 glycaemic control, three blood pressure, and one cholesterol control. Clinicians struggle to meet evolving treatment targets within limited time and resources, and are frustrated with resulting compromises. They lack confidence in knowledge of guidelines and skills, notably initiating insulin and facilitating patient behaviour change. Changing professional boundaries have resulted in uncertainty about where clinical responsibility resides. Accounts are often couched in emotional terms, especially frustrations over patient compliance and anxieties about treatment intensification.

\section{Conclusion}

Although resources are important, many barriers to improving care are amenable to behaviou change strategies. Improvement strategies need to account for differences between clinical targets and consider tailored rather than "one size fits all' approaches. Training targeting knowledge is necessary but insufficient to bring about major change; approaches to improve diabetes care need to delineate roles and responsibilities, and address clinicians' skills and emotions around treatment intensification and facilitation of patient behaviour change.

\section{Keywords}

diabetes mellitus, type 2; primary health care; qualitative research; quality improvement; systematic review.

\section{INTRODUCTION}

Diabetes mellitus is a global health problem affecting both developed and resource-limited countries. ${ }^{1,2}$ The World Health Organization (WHO) estimates that 347 million people worldwide have diabetes, with deaths from diabetes projected to double between 2005 and 2030. ${ }^{3}$ Diabetes also causes considerable morbidity related to macro- and microvascular damage, and to psychosocial sequelae, ${ }^{4-6}$ and incurs significant and growing healthcare costs. ${ }^{\text {? }}$

Despite the availability of evidence-based guidance, ${ }^{8-10}$ and encouraging trends in the delivery of care, many patients with diabetes do not achieve the recommended glycaemic cholesterol, and blood pressure levels., ${ }^{2,1}$ Most routine diabetes management, particularly of type 2 diabetes, is undertaken in primary care, drawing on features of the chronic care model such as dedicated review clinics, ${ }^{12}$ and shared care with specialists. $^{13}$

Interventions to improve diabetes care generally have modest effects. ${ }^{14}$ Understanding influences on clinical behaviour is critical in guiding the selection and enhancement of interventions to improve practice. $^{15,16}$ Patient-reported influences on the receipt and outcome of diabetes care are well documented. ${ }^{17-21}$ However, much variation in delivery and outcomes is not readily explained by patient characteristics, and is likely to be attributable to clinician and organisational behaviour. ${ }^{22}$ Qualitative studies were reviewed that examined primary care clinicians' perceived barriers

B Rushforth, MA (Cantab), MA, MRCGP, DFSRH DRCOG, GP. Foundry Lane Surgery, Leeds. C McCrorie, MA, research fellow; L Glidewell, MA, MSc, PhD, FHEA, lecturer; E Midgley, BMBCh (Oxon), GP specialty trainee; R Foy, MSc, PhD, MRCGP, MFPHM, DCH, professor of primary care, Leeds Institute of Health Sciences, University of Leeds, Leeds.

\section{Address for correspondence}

Bruno Rushforth, Foundry Lane Surgery, 95 to and enablers of recommended practice for type 2 diabetes.

\section{METHOD}

\section{Search strategy}

Search strategies were combined for papers on clinicians' perceptions and type 2 diabetes from the Cochrane Metabolic and Endocrine Disorders Group together with qualitative methodological filters (the full search strategy is available from the authors on request). ${ }^{23}$ MEDLINE, Embase, CINAHL, Psyclnfo, and ASSIA were searched from 1980, the year the WHO report recommended integrating diabetes care within community-based healthcare systems, ${ }^{24}$ until the first week in March 2014, and reference lists of included studies were hand searched.

\section{Study selection}

Qualitative studies were included that described primary care physicians' or nurses' perceptions of type 2 diabetes management. Papers were included that either focused on specific treatment goals (such as glycaemic control) $)^{8,11,25}$ or more general aspects of care. Papers were excluded that examined other specific care processes (for example, management of concurrent depression) and quantitative surveys.

Paired reviewers independently screened titles and abstracts of all identified references. Inconsistencies were examined in decisions after 100 and 500 references, and inclusion criteria were refined. Paired

Moresdale Lane, Leeds LS14 6GG, UK

E-mail: bruno.rushforthanhs.net

Submitted: 23 February 2015; Editor's response: 1 June 2015; final acceptance: 28 July 2015.

\section{(CBritish Journal of General Practice}

This is the full-length article (published online 29 Jan 2016) of an abridged version published in print. Cite this article as: $\mathbf{B r} \mathbf{J}$ Gen Pract 2016; DOI: 10.3399/bjgp16X683509 


\section{How this fits in}

Type 2 diabetes is a global health problem with many patients failing to achieve recommended treatment goals. Most routine type 2 diabetes management is undertaken in primary care. Barriers to care include knowledge and resources, but also uncertainties about professional role boundaries, and clinicians' anxieties regarding treatment decisions. Strategies to improve type 2 diabetes care need to address clinicians' skills and emotions around treatment intensification and facilitation of patient behaviour change.

reviewers independently assessed full-text articles. Disagreements were resolved by discussion. Non-English studies were identified but their data were not extracted.

\section{Data extraction}

Single reviewers extracted data on study details, perceptions, and quality assessment. Perceived barriers and enablers to the 14 domains of the Theoretical Domains Framework ${ }^{26}$ were coded using NVivo 10 (further details are available from the authors on request). This framework draws on psychological theories to group influences on behaviour and hence categorise implementation problems. ${ }^{27,28}$ Data were further coded to treatment goals (such as glycaemic control) and as primarily clinician, patient, or organisational related.

Asecond reviewer checked data extraction and coding, resolving disagreement by discussion. Initial calibration exercises

${ }^{a}$ Two papers describe data taken from the same study. 30,31 were undertaken involving independent data extraction and coding on a pilot sample of three papers and the coding was further clarified. Intra-coder reliability was judged to be adequate after recoding an early included study at the end of the data extraction phase.

\section{Quality assessment}

After initial calibration exercises one researcher assessed study quality using the National Institute for Health and Care Excellence (NICE) checklist for qualitative studies. ${ }^{29}$

\section{Data synthesis and analysis}

The findings were organised within a grid comprising the 14 theoretical domains. Gaps were identified in the grid to highlight influences not reported in the literature. The relative proportions of patient, clinician, and organisational factors represented in each domain and for each targeted behaviour were assessed. In reporting results, physicians and nurses are referred to as 'clinicians' but separate terms are used when appropriate.

\section{RESULTS}

From 3360 records, 172 full-text papers were assessed, with 32 studies included in the qualitative synthesis (Figure 1 and Appendix 1). Over half of the studies included were from the US (11 studies) or the UK (seven). Nineteen studies conducted individual qualitative interviews lone structured, nine semi-structured, and nine unspecified), eight focus groups, and five combinations of these. The main treatment goals were general diabetes management in 17 studies, glycaemic control in 11 (nine focusing on insulin initiation), blood pressure in three studies, and cholesterol control in one.

Influences on clinical practice ranged across all 14 theoretical domains (Table 1 ; more detailed summaries grouped by glycaemic control and blood pressure are available from the authors on request). The most commonly occurring and salient domains comprised environmental context and resources, knowledge, and skills loften coded together), professional role and identity, and emotion.

\section{Environmental context and resources}

Clinicians consistently describe limited resources or environmental constraints as barriers, especially in relation to achieving glycaemic control or general aspects of care. Large workload and resulting time pressures undermine clinicians' abilities to 
deliver care to their own satisfaction:

'It is a burden on one doctor to see 30 or more patients, we had to do a lot of things to each patient in addition to documentation of the findings in the computer.'(Physician) 32

Clinicians express concern about the resources available, including for patient education, given rising demand and expectations:

'The huge thing, which is raising its head alreadyand will in the future, is the enormous burden of people with diabetes. The everincreasing demand to reach tighter and tighter guidelines, and the limited resources available to help us do that ... '(Physician) ${ }^{33}$

Given the increased number of patients managed in primary care, specialists can play an important guiding role, although communication is not always optimal:

I generally tell people that once they have been to see a specialist that they come back and see me afterwards and tell me what happened, that's my way of finding out. And we obviously get letters which are quite often not actually of sufficient depth to be of much use to us.' (Physician) $)^{34}$

A wide range of organisation-level factors affect care, such as the availability of information technology and protocols to structure diabetes care, lack of personal continuity of care, and limited continuing education opportunities for clinicians (Table 1).

Clinicians also recognised patients socioeconomic and occupational circumstances as significant problems, especially in enabling self-management:

You know, if they're not in very good housing ... they've perhaps got young children or if life's stacked against them anyway, then I don't think they're as able to make the [suggested lifestyle] changes.' (Nurse) ${ }^{35}$

'The minute people are on shift work, it's really hard for them to control everything, from remembering to take their pills when they're home and when they're not, when they're at work and when they're not. (Physician) $^{36}$

They also acknowledged limitations imposed by comorbidities:

'It's become something ... of a spiral here... [arthritis] has reduced his ability to exercise, which has made his weight go up, which has made his diabetic control worse. '(Physician) ${ }^{37}$

Such factors, often outside of patients' and clinicians' loci of control, collectively engender helplessness in the face of immutable adversity.

\section{Knowledge and skills}

Limited knowledge and skills among patients and clinicians hinder achievement of glycaemic, cholesterol, and blood pressure goals. Physicians find it difficult to recall or keep up with changing recommendations. ${ }^{38}$ Clinicians lacked confidence in treatment intensification, especially when considering insulin:

'There's not always somebody to ask [for advice] and there's no protocol, so the easiest thing is to just send [the patient] to the hospital ... and let them make the decision for you [about starting insulin].' (Physician) $^{39}$

Clinicians recognise the importance of supporting changes in patient behaviour but lack effective strategies:

... there are some patients that I just can't get to make changes, despite my best efforts.' (Physician) ${ }^{37}$

'Providers complained that they had received insufficient training in medical school and in their residencies to promote behavioural change ... As one physician noted, most providers can treat conditions that require only medications pretty well, but "not many give good advice for diabetes". "40

Clinicians recognised that patients often need a lot of support to adhere to selfmanagement plans:

'One client was documenting "error" every time [the blood glucose] meter said error ... no one had explained this meant error with machine/strip.' (Nurse) ${ }^{41}$

'... people don't understand blood pressure. I don't think they really understand what we're [trying to do]. '(Nurse) ${ }^{35}$

Therefore, clinicians consider patient education important but are concerned about overloading patients with information and doubt the effects of lifestyle counselling.

\section{Professional role and identity}

Nurses' and physicians' roles have evolved as diabetes care has become integrated into 


\section{Table 1. Coding of extracts to Theoretical Domains Framework ${ }^{26}$ and clinical target}

\begin{tabular}{lll} 
Domain & $\begin{array}{l}\text { Clinical } \\
\text { target }\end{array}$ & Clinician-related factors \\
\hline $\begin{array}{l}\text { Environmental } \\
\text { context and }\end{array}$ & General & Families not invited for lifestyle modification \\
resources & & discussions.$^{48}$
\end{tabular}

\section{Patient-related factors}

Patients' socioeconomic

situation, occupation, carer

status, comorbidities, mobility problems, polypharmacy, and selfempowerment capacity acting as barriers to care. ${ }^{32,33,35,37,42,47-51}$

Glycaemic Nurses feeling isolated in role as single control diabetes nurse in practice when considering converting to insulin. ${ }^{43}$

\section{Cholesterol}

control

Blood

pressure

\section{Knowledge \\ lextracts in}

Knowledge

domain with *

also coded to

Skills domain)

Glycaemic Initiating insulin seen as a simple process by control

Cholesterol

control

Blood

pressure

Lack of knowledge in self and among colleagues about causes, evidence base, guidelines, services, required lifestyle and cultural beliefs; clinician-education as to date. ${ }^{32,40,42,44^{*}, 46^{*}, 47^{*}, 48,50,53,61^{*}}$ some; clinician confidence and uncertainty in how to initiate insulin; inaccurate beliefs about self-monitoring; and limited familiarity/uncertainty with guideline recommendations. ${ }^{32 *, 33,39 *, 41,42^{*}, 43^{*}, 47 *, 59 *}$

\section{Insufficient knowledge of guideline}

recommendations. ${ }^{38}$ changes, patient self-management education facilitator of care; and nurses seen as more up

General

\section{Social/} General

professional

role and

identity
Accommodating insulin therapy with patients' lifestyles; patients ability to care for themselves adversely affected by physical impairments; and patients' limited financial resources affecting decisions about starting insulin. ${ }^{30,31,39}$

Patients' financial situation and occupational constraints acting as a barrier to care. ${ }^{36}$

\section{Clinician-patient education gap}

with patients' knowledge deficits leading to non-compliance coupled with concern about information overload and whether education effective. ${ }^{35,42,45,46 *}, 48,49 * 51$

Limited knowledge of: self-testing insulin use; erectile dysfunction on insulin; age when insulin required; and long-term effects of diabetes. $^{26,33,39 *, 41,58}$

Insufficient knowledge leading to discontinuation of medicine..$^{38}$

Level of understanding affecting amount of information given about BP control. 35,36

Taking responsibility for managing diabetes balanced with expediency of a paternalistic approach. ${ }^{45-47}$

\section{Organisational-related factors}

Workload and time pressures; inadequate funding and staff numbers (clinical and administrative); role of structured management systems; access issues for patients, including to self-management education; mixed relationships and communication with specialist teams; limited services for specific patient-groups (for example, older people); role of insurance companies in driving diseasemanagement activity; lack of public health support for prevention awareness; lack of agreed national management protocol; and continuing clinical education provision. ${ }^{32,34,35,37,40,42,45-49,51,52,53-55}$ Lack of evidence base and clear guidelines; inadequate funding for equipment; workload; time pressures; staffing levels, language skills, and roles (for example, nurse educators); patient support; availability of interpreters; lack of same-physician continuity of care; access to and communication with specialist teams; the need for protocols; and advantages of primary care management. ${ }^{30,33,39,42-44,56-59}$

Lack of structured approach to diabetes management. ${ }^{38}$

Workload and time pressures, preferences of paper-based systems, and inadequate financial compensation. ${ }^{36,60}$

Problems of coordination between professionals' and nurses' existing multiple responsibilities..$^{40,48}$

Glycaemic Nurses as complementary to physicians' role; Sometimes reluctant but

control concernas to where responsibility lay; diabetes empowered by greater involvement care as part of an ongoing relationship with the in their diabetes care; finding patient; closer liaison with secondary care a insulin treatment socially solution. ${ }^{42,58,60}$

embarrassing. $41,44,58$

Cholesterol Lack of perceived responsibility; secondary

control care's role. $^{38}$

Blood Role of other primary care professionals and pressure patients in BP target decisions. ${ }^{35}$ 


\section{Table 1 continued. Coding of extracts to Theoretical Domains Framework ${ }^{26}$ and clinical target}

\begin{tabular}{|c|c|c|}
\hline Domain & $\begin{array}{l}\text { Clinical } \\
\text { target }\end{array}$ & Clinician-related factors \\
\hline \multirow[t]{4}{*}{ Emotion } & General & $\begin{array}{l}\text { Frustration at patients compliance levels and } \\
\text { prognosis uncertainty/timeframe, and using } \\
\text { scare tactics with patients. } 32,37,40,42,45-47,58,61\end{array}$ \\
\hline & $\begin{array}{l}\text { Glycaemic } \\
\text { control }\end{array}$ & $\begin{array}{l}\text { Feeling overwhelmed by the clinical picture; } \\
\text { preventing burnout by partnership working; } \\
\text { fear of inducing hypoglycaemia; frustration } \\
\text { with: the complexity of regimens, poor control } \\
\text { of those with different ethnic backgrounds, and } \\
\text { limited evidence base for older people. }{ }^{33,39,42,57,59}\end{array}$ \\
\hline & $\begin{array}{l}\text { Cholesterol } \\
\text { control }\end{array}$ & $\begin{array}{l}\text { Frustration at patients non-compliance and } \\
\text { fears about medication side effects. }{ }^{38}\end{array}$ \\
\hline & Blood & Perceived reward of controlling BP. ${ }^{36}$ \\
\hline
\end{tabular}
diabetes control and causing anxiety

\begin{tabular}{|c|c|c|}
\hline $\begin{array}{l}\text { Beliefs about } \\
\text { consequences }\end{array}$ & General & $\begin{array}{l}\text { Pros/cons of tailored medication } \\
\text { intensification; the centrality of the clinician- } \\
\text { patient relationship, including patient } \\
\text { education. } 37,40,42,46,47,50,56,61\end{array}$ \\
\hline
\end{tabular}

Glycaemic Concerns around: older patients' response control to medication; urine testing; and starting insulin, although some advantages recognised: physicians' beliefs about consequences of diabetes shaped by medical school exposure. $33,41-43,39,58,61$

Cholesterol Concerns about side effects of medication. ${ }^{38}$ control

Blood Vigorous' guidelines encourage more pressure aggressive management. ${ }^{36}$

\begin{tabular}{|c|c|c|}
\hline \multirow[t]{3}{*}{$\begin{array}{l}\text { Skills lextracts } \\
\text { in Knowledge } \\
\text { domain with* } \\
\text { also coded to } \\
\text { Skills domain) }\end{array}$} & General & $\begin{array}{l}\text { Importance of interpersonal skills facilitating } \\
\text { holistic care, good communication, and } \\
\text { behaviour change skills, although can be } \\
\text { a mismatch between training and real-life } \\
\text { practice. } 32,34,37,40,45,46,52,54\end{array}$ \\
\hline & $\begin{array}{l}\text { Glycaemic } \\
\text { control }\end{array}$ & $\begin{array}{l}\text { Ability to maintain skills in insulin } \\
\text { conversion. }{ }^{43}\end{array}$ \\
\hline & $\begin{array}{l}\text { Blood } \\
\text { pressure }\end{array}$ & - \\
\hline $\begin{array}{l}\text { Social } \\
\text { influences }\end{array}$ & General & $\begin{array}{l}\text { The 'superior' specialist having a different } \\
\text { message for the patient. }{ }^{45}\end{array}$ \\
\hline
\end{tabular}

Glycaemic Perceived pressure to take on the control responsibility for converting patients to insulin; nurses struggling to achieve external legitimacy in insulin initiation. ${ }^{43,59}$

Beliefs about General Variation in abilities to adopt proactive
capabilities medication if out-of-clinic BP
Patients' ability to self-care influencing clinicians' decisions whether to initiate insulin. ${ }^{31}$

Those with poor technical skills could struggle with telemedicine..$^{60}$ Influence of family and cultural beliefs, and specific problems with hard-to-reach or isolated groups. $32,37,42,45,47,48,51$

Community and spiritual/religious

beliefs affecting views about insulin. 30,44

\section{Reliance on medication rather than} strategies to change patients' behaviour,

\section{Patient-related factors}

Depression, anxiety, and fear barriers to self-management, although emotional response can be an opportunity for behaviour change. $32,37,47$

Fear of needles, weight gain, and hypoglycaemia with insulin, and with the connotations of 'drastic' measures. ${ }^{30,33,39,41,42}$

Life stresses taking priority ove when discussing BP monitoring or control. 35,36,60

Cultural beliefs affecting treatment decisions; non-compliance due to complexity or pain; yet motivated by significant changes in management; and opportunistic diabetes care seen as a dismissal of patients' primary complaint. 32,40,47,48,50,52

Lack of appreciation of effects of poor control; belief that diet and exercise changes would suffice compliance issues with medication intensification; belief that insulin could cause complications; and faith in traditional remedies $30,33,39,58,61$

Reluctance to start medication due to side effects. ${ }^{38}$

Resistance to taking additiona readings lower than in clinic. ${ }^{60}$

\section{Organisational-related factors}

Feeling overwhelmed by workload and guidelines, and frustrated when secondary care transfer patients with drugs that cannot be prescribed within primary care. $32,47,48,62$
Increased attention to diabetes in health care and the media but a lack of public health campaigns to highlight the seriousness of the condition..$^{40,51}$

circumstances or diabetic control, and low levels of trust in non-physician colleagues abilities. $^{32,37,40,45,48,53}$ 
primary care, with nurses playing a central role. ${ }^{42}$ However, both physicians and nurses express uncertainty or disagreement over who is responsible for various elements of patient care across both primary and secondary care: ambiguity about who was responsible for managing diabetes care contributed to difficulty coordinating care with other providers such as pharmacists, diabetes educators, and endocrinologists. (Physicians) $^{37}$

\section{Table 1 continued. Coding of extracts to Theoretical Domains Framework ${ }^{26}$ and clinical target}

\begin{tabular}{|c|c|c|c|c|}
\hline Domain & $\begin{array}{l}\text { Clinical } \\
\text { target }\end{array}$ & Clinician-related factors & Patient-related factors & Organisational-related factors \\
\hline & $\begin{array}{l}\text { Glycaemic } \\
\text { control }\end{array}$ & $\begin{array}{l}\text { Relative inexperience and lack of } \\
\text { confidence prescribing insulin; nurses } \\
\text { better at guideline adherence. }{ }^{30,33,39,43}\end{array}$ & $\begin{array}{l}\text { Concern that those with } \\
\text { impairments or older people } \\
\text { could find complicated regimens } \\
\text { difficult. } 33,42\end{array}$ & - \\
\hline \multirow[t]{3}{*}{ Reinforcement } & General & $\begin{array}{l}\text { Collegial support to improve treatment in } \\
\text { difficult patients and not wanting to 'nag' } \\
\text { patients. }{ }^{45.46}\end{array}$ & $\begin{array}{l}\text { Physical disability and lack of } \\
\text { immediate response to treatment } \\
\text { affecting engagement; patient } \\
\text { compliance affected only by major } \\
\text { adverse events. } 32,40,42\end{array}$ & - \\
\hline & $\begin{array}{l}\text { Glycaemic } \\
\text { control }\end{array}$ & $\begin{array}{l}\text { Reinforcement of clinical judgements } \\
\text { by specialist colleagues and patients' } \\
\text { assessments; referring to specialists about } \\
\text { whom there had been positive feedback. }{ }^{33,57}\end{array}$ & $\begin{array}{l}\text { Symptom improvement and } \\
\text { emphasising the value of treatment } \\
\text { to reinforce practice. }{ }^{33,44}\end{array}$ & Incentive payments for insulin initiation. ${ }^{59}$ \\
\hline & $\begin{array}{l}\text { Blood } \\
\text { pressure }\end{array}$ & $\begin{array}{l}\text { Using raised BP readings to reinforce lifestyle } \\
\text { advice. }^{35}\end{array}$ & - & - \\
\hline \multirow[t]{4}{*}{ Intentions } & General & $\begin{array}{l}\text { Compliance, avoidance of complications, and } \\
\text { professional conscience as motivators. }{ }^{34,49,50}\end{array}$ & $\begin{array}{l}\text { Non-compliance with diet or } \\
\text { treatment despite awareness of } \\
\text { consequences. }{ }^{42,47}\end{array}$ & - \\
\hline & $\begin{array}{l}\text { Glycaemic } \\
\text { control }\end{array}$ & - & $\begin{array}{l}\text { Non-compliance with dietary } \\
\text { practices except before clinic visits. }{ }^{48}\end{array}$ & - \\
\hline & $\begin{array}{l}\text { Cholesterol } \\
\text { control }\end{array}$ & - & $\begin{array}{l}\text { Medication 'intentional non- } \\
\text { compliance' } 38\end{array}$ & - \\
\hline & $\begin{array}{l}\text { Blood } \\
\text { pressure }\end{array}$ & - & $\begin{array}{l}\text { Non-compliance related to personal } \\
\text { attitude to diabetes. }{ }^{36}\end{array}$ & - \\
\hline \multirow[t]{3}{*}{$\begin{array}{l}\text { Behavioural } \\
\text { regulation }\end{array}$} & General & $\begin{array}{l}\text { Visual prompts; self-management education; } \\
\text { reluctance to 'nag'; and getting used to } \\
\text { developments in care. }{ }^{32,42,45,51}\end{array}$ & $\begin{array}{l}\text { Challenge of being disciplined to } \\
\text { achieve good diabetic control. }{ }^{42}\end{array}$ & - \\
\hline & $\begin{array}{l}\text { Glycaemic } \\
\text { control }\end{array}$ & - & $\begin{array}{l}\text { Insulin dose changes following self- } \\
\text { monitoring and selective timing of } \\
\text { adherence to diet. } 41,48\end{array}$ & - \\
\hline & $\begin{array}{l}\text { Blood } \\
\text { pressure }\end{array}$ & - & - & $\begin{array}{l}\text { Immediate feedback to patients with } \\
\text { telemedicine systems. }{ }^{60}\end{array}$ \\
\hline \multirow[t]{2}{*}{ Optimism } & General & $\begin{array}{l}\text { Feeling positive about preventing complications } \\
\text { by early intervention. }{ }^{46}\end{array}$ & $\begin{array}{l}\text { Lack of a positive approach to self- } \\
\text { care and minimising the condition, } \\
\text { particularly if asymptomatic. }{ }^{37,45,47}\end{array}$ & - \\
\hline & $\begin{array}{l}\text { Cholesterol } \\
\text { control }\end{array}$ & $\begin{array}{l}\text { Near-target lipid achievement believed to be } \\
\text { adequate for some patients. }{ }^{38}\end{array}$ & - & - \\
\hline \multirow[t]{2}{*}{$\begin{array}{l}\text { Memory, } \\
\text { attention, } \\
\text { and decision } \\
\text { processes }\end{array}$} & General & $\begin{array}{l}\text { Using memory rather than guidelines } \\
\text { to determine care needs but problems } \\
\text { remembering and danger of overloading } \\
\text { patients with information. }{ }^{45,52}\end{array}$ & $\begin{array}{l}\text { Delayed decisions by patients to start } \\
\text { insulin due to perceived conflicting } \\
\text { information from peers, the media, } \\
\text { and healthcare professionals; being } \\
\text { unable to sustain lifestyle changes } \\
\text { once a lifestyle programme has } \\
\text { ended. }{ }^{30,51}\end{array}$ & - \\
\hline & $\begin{array}{l}\text { Glycaemic } \\
\text { control }\end{array}$ & $\begin{array}{l}\text { Collusion with patients to avoid starting } \\
\text { insulin. } 42\end{array}$ & - & - \\
\hline \multirow[t]{2}{*}{ Goals } & General & $\begin{array}{l}\text { The need to prioritise care processes and } \\
\text { individualise goals for the patient. }{ }^{46,52}\end{array}$ & $\begin{array}{l}\text { Patients' lack of ambition, interest, } \\
\text { and engagement. }{ }^{62}\end{array}$ & - \\
\hline & $\begin{array}{l}\text { Glycaemic } \\
\text { control }\end{array}$ & $\begin{array}{l}\text { Converting patient to insulin allowing nurses to } \\
\text { see[ing] the job through'. } 43\end{array}$ & - & - \\
\hline
\end{tabular}

$B P=$ blood pressure. Note: clinical targets extracts coded to: general diabetes care; glycaemic control; cholesterol control; BP control; foot exam; smoking; weight management; urine albumin-creatinine ratio/equivalent 
'The fact that insulin conversion involves setting dosage levels seemed to be at the root of [nurses'] concern [about accountability], and this was perceived as a major shift in responsibility ... "I think we've got to recognise the level of responsibility and the GPs have got to recognise that and pay us appropriately".' (Nurse) $)^{43}$

Clinicians also harbour doubts over how ready patients are to embrace selfmanagement roles. ${ }^{41,44}$ Some physicians subsequently feel that a more physiciancentred approach is justified by patient preferences, expediency, or pressures to improve outcomes:

'GPs often become directing and paternalistic in order to cope more easily [with barriers to care]. '(Physicians) ${ }^{45}$

\section{Emotion}

Clinicians experience a range of often negative emotions in dealing with diabetes, especially around patient compliance to management plans or adverse effects of treatment, and employ varying approaches to dealing with emotions in patient care. They become frustrated at patients compliance to advice:

We just give them the medicine ... and the next time they come in we ask them if they've taken it and they say "No". That frustrates us [because] ... the patient doesn't want to change for the better.'(Physician) ${ }^{37}$

Clinicians also have concerns about treatment side effects:

Fear of side effects ... also mentioned as reasons not to start lipid-lowering medication at that moment.' (Physicians) ${ }^{38}$

... reluctant to initiate treatment, fearing that it would induce hypoglycaemia in the patient.' (Physicians) ${ }^{39}$

However, success is professionally rewarding:

'These miraculous patients, who had followed their doctor's orders in [sic] the letter, served as a relief [to the GPs]. (Physicians) 46

Some physicians admit to exploiting emotions as leverage to change patients behaviour, including patients' initial anxiety at diagnosis:

Some doctors mentioned that they expressed aggression towards the non-adherent patients and sometimes they frightened them with the potential complications of diabetes.' (Physicians) ${ }^{32}$

When people are feeling more anxious about their disease they're more likely to want to absorb information and make health changes around their lifestyle.' (Physician) ${ }^{47}$

Clinicians recounted patients' fears of needles and hypoglycaemia when discussing insulin, but also used the threat of insulin as a way of signalling the need for major change:

"The very words "needle" or "injection" carried complex connotations and, sometimes, the suggestion of starting insulin could signify a message of failure in other therapies to the patient, that is, that "drastic" measures were now needed." (Physicians) $^{33}$

\section{Other domains}

Beliefs about consequences, social influences, and (lack of) reinforcement emerged as further key influences on treatment targets and general aspects of care. Clinicians recognise that treatment intensification can cause more harm than good, particularly in older patients. ${ }^{42}$ Wider social influences also feature in several studies, including family, community, and cultural beliefs:

'I think they [patients] were thinking that the insulin is from, what do you call this, nonhalal ("lawful”) ... products.' (Physician) ${ }^{30}$

Clinicians recognise the lack of reinforcement through delayed responses to treatment and patients tendencies to minimise their condition:

... it is easier to modify treatments in conditions with definite symptoms and more gratifying when treatments provide immediate relief, neither of which applies to diabetes.' (Physicians and nurses) ${ }^{40}$

'[Physicians] also remarked that diabetes patients tend to minimise their disease. This really is in contrast with the GP's objectives. ${ }^{45}$

One study notably suggested collusion to avoid insulin initiation:

[Patients] see [starting insulin] as being their point of failure almost. I think that 
some patients can be very persuasive to us to let you say you don't want me on insulin. The patients don't want to go on it. So there is a joint tendency that they don't go on it. (Physician or nurse - unspecified) ${ }^{42}$

\section{Robustness of findings}

Most included studies scored favourably on the NICE study quality checklist (details available from the authors on request). The role of the researcher and methods and analysis were often inadequately reported to allow reliable judgements.

\section{DISCUSSION}

\section{Summary}

Primary care clinicians face multiple challenges in the inherently complex management of diabetes. They struggle to meet evolving treatment targets within limited time and resources, and express frustrations with resulting compromises in care. Clinicians lack confidence in their knowledge of guidelines and skills in particular tasks, such as initiating insulin and facilitating patient behaviour change. Despite continuing policy drives to promote self-management, clinicians often find it hard to share responsibility effectively with patients and support behaviour change. Changing role boundaries, between primary and secondary care, and also between physicians and nurses within primary care have generated uncertainty and unease about where clinical responsibility resides. Many accounts were couched in emotional terms, especially frustrations over patient compliance with treatment and anxieties about treatment intensification.

\section{Strengths and limitations}

This study has six main limitations. First, perceived may differ from actual barriers and enablers. Nevertheless, quality improvement strategies specifically need to target such perceptions; these may be more amenable to change than major resource and structural constraints. ${ }^{63}$ Second, review findings depend on the methods of included studies; possible under-reporting was noted within certain domains. For example, given that diabetes is a complex, multifaceted condition for both clinicians and patients to manage, it is surprising that problems with memory and attention processes emerged relatively infrequently. This may be due to under-detection in the original studies or such factors simply being less important. Third, grey and non-English language literature was not included. However, checks of reference lists of included studies suggested that most relevant studies had been identified. Fourth, most studies were from the US or the UK; the findings could therefore overrepresent clinician experience from these territories. However, similar themes were found in studies spanning the Middle and Far East, and other European countries, suggesting that many factors are universal. Fifth, qualitative systematic review methods are still evolving, with variable approaches to evidence synthesis. ${ }^{64}$ This study used an explicit framework to organise the findings, ${ }^{26}$ and followed reporting guidance. ${ }^{65}$ Sixth, although first-hand patient perspectives were not examined, the study focused specifically on what clinicians believe about patient influences on care.

\section{Comparison with existing literature}

Understanding clinicians' beliefs is critical in designing more effective improvement strategies. This study drew on an organising framework to identify environmental and behavioural influences potentially amenable to change through linked behaviour change techniques. ${ }^{66-68}$ An additional 12 studies were found that were published after an earlier review. ${ }^{69}$ Although uncertainty about professional roles and clinical responsibility was also identified, several key barriers notably persist, suggesting limited progress over recent years to address recognised barriers to care. In contrast with a review of patient perspectives suggesting preferences for achieving glycaemic control over minor hypoglycaemic events, ${ }^{70}$ this study found that clinicians reported significant fears among both patients and clinicians around inducing hypoglycaemia.

The clinical management of type 2 diabetes is evolving and becoming more structured. Tricco and colleagues' metaanalysis of randomised trials ${ }^{14}$ suggests that quality improvement focusing on systematic chronic disease management and patient involvement is particularly effective in achieving treatment goals. ${ }^{11}$ The findings, especially those indicating time constraints and uncertainties in professional roles and responsibility, suggest that much scope still exists for improving the organisation of care, even within better developed primary care systems. Significant progress here is likely to depend on concerted action across different levels of healthcare systems. ${ }^{71}$ Tricco and colleagues also found that interventions solely targeting clinicians, such as education or feedback of performance data, appeared less effective. ${ }^{14}$ However, the rationales and behaviour change techniques underpinning such interventions are often poorly developed 
and described, limiting cumulative learning that can enhance effects. ${ }^{72,73}$ A range of modifiable clinician perceptions that behaviour change strategies could target more effectively were identified, such as belief in self-efficacy around initiating insulin and facilitating patient behaviour change.

\section{Implications for research and practice}

There is clearly a challenge around addressing clinicians' pessimism around patient behaviour change. Some of this pessimism is understandable given the limited impacts of structured patient education programmes. ${ }^{74}$ Such policies are unlikely to bear fruit if clinicians have nihilistic attitudes and lack training in behavioural approaches. This study found that emotional factors repeatedly featured in clinicians' accounts, consistent with studies highlighting emotional influences on other professional behaviours. ${ }^{75,76}$ Both clinicians and patients express anxiety and uncertainty about how best to manage diabetes. Clinicians further recognise that both they and patients can suffer from information overload. Rationalist approaches based largely on improving knowledge about the technical aspects of care are likely to have a limited impact on professional behaviour and patient outcomes. Therefore, future research to improve the delivery of diabetes care could focus on equipping clinicians with skills of facilitating behaviour change while managing engendered emotions.

Some barriers to recommended care varied according to the treatment goal. Different clinical behaviours and targets require different intervention approaches rather than a 'one size fits all' approach. ${ }^{77}$ However, it is possible to incorporate a range of behaviour change techniques within implementation interventions commonly used in primary care, such as computerised prompts or audit and feedback. ${ }^{78}$ Improvement strategies should also address both organisational and individual levels, for example, clarifying primary care team roles and responsibilities, and training clinicians to support patient behaviour change, respectively.

\section{Funding}

This study is the independent work of the authors. Bruno Rushforth was funded by a National Institute for Health Research (NIHR) In-Practice Fellowship while undertaking the systematic review. The views expressed are those of the authors and not necessarily those of the NHS, the $\mathrm{NIHR}$, or the Department of Health.

\section{Ethical approval}

Not required.

\section{Provenance}

Freely submitted; externally peer reviewed.

\section{Competing interests}

The authors have declared no competing interests.

\section{Acknowledgements}

Thanks to Judy Wright for assistance with constructing searches and lan McDermott for helpful comments on an earlier draft. Wendy Hobson kindly assisted with references and table formatting.

\section{Discuss this article}

Contribute and read comments about this article: bjgp.org/letters 


\section{REFERENCES}

1. World Health Organization. 2008-2013 Action plan for the global strategy for the prevention and control of noncommunicable diseases. Geneva: WHO, 2009.

2. Diabetes UK. State of the nation 2013 England. London: Diabetes UK, 2013.

3. World Health Organization. Diabetes programme. http://uww.who.int/diabetes/ en/ laccessed 5 Nov 2015).

4. Goldney RD, Phillips PJ, Fisher LJ, Wilson DH. Diabetes, depression, and quality of life: a population study. Diabetes Care 2004; 27(5): 1066-1070.

5. National Institute for Health and Care Excellence. Depression in adults with a chronic physical health problem: recognition and management. CG91. London: NICE, 2009. mww.nice.org.uk/guidance/cg91/ (accessed 5 Nov 2015).

6. Carney RM, Freedland KE, Miller GE, Jaffe AS. Depression as a risk factor for cardiac mortality and morbidity: a review of potential mechanisms. J Psychosom Res 2002; 53(4): 897-902

7. Hex N, Bartlett C, Wright D, et al. Estimating the current and future costs of Type 1 and Type 2 diabetes in the UK, including direct health costs and indirect societal and productivity costs. Diabet Med 2012; 29(7): 855-862

8. National Institute for Health and Care Excellence. Type 2 diabetes: the management of type 2 diabetes. CG87. London: NICE, 2009. http://umw.nice.org. uk/guidance/cg87 (accessed 5 Nov 2015).

9. American Diabetes Association. Standards of medical care in diabetes 2014 Diabetes Care 2014; 37(Suppl 1): S14-S80.

10. World Health Organization. Prevention and control of noncommunicable diseases: guidelines for primary health care in low-resource settings. Geneva: WHO, 2012. http://apps.who.int/iris/bitstream/10665/76173/1/9789241548397_eng.pdf laccessed 5 Nov 2015).

11. Health and Social Care Information Centre. National Diabetes Audit 2012-2013. report 1: care processes and treatment targets. Leeds: HSCIC, 2014. http://uww. hscic.gov.uk/catalogue/PUB14970 (accessed 5 Nov 2015).

12. Bodenheimer T, Wagner EH, Grumbach K. Improving primary care for patients with chronic illness. JAMA 2002; 288(14): 1775-1779.

13. Smith S, Bury G, O'Leary M, et al. The North Dublin randomized controlled trial of structured diabetes shared care. Fam Pract 2004; 21(1): 39-45.

14. Tricco AC, Ivers NM, Grimshaw JM, et al. Effectiveness of quality improvement strategies on the management of diabetes: a systematic review and metaanalysis. Lancet 2012; 379(9833): 2252-2261.

15. Grol R. Personal paper. Beliefs and evidence in changing clinical practice. BMJ 1997; 315(7105): 418-421

16. Baker R, Camosso-Stefinovic J, Gillies C, et al. Tailored interventions to overcome identified barriers to change: effects on professional practice and health care outcomes. Cochrane Database Syst Rev2010; (3): CD005470.

17. Dietrich UC. Factors influencing the attitudes held by women with type II diabetes: a qualitative study. Patient Educ Couns 1996; 29(1): 13-23.

18. Holmström IM, Rosenqvist U. Misunderstandings about illness and treatment among patients with type 2 diabetes. J Adv Nurs 2005; 49(2): 146-154.

19. Hunt LM, Valenzuela MA, Pugh JA. NIDDM patients' fears and hopes about insulin therapy. The basis of patient reluctance. Diabetes Care 1997; 20(3): 292-298.

20. Lai WA, Lew-Ting CY, Chie WC. How diabetic patients think about and manage their illness in Taiwan. Diabet Med 2005; 22(3): 286-292.

21. Lawton J, Peel E, Parry O, et al. Lay perceptions of type 2 diabetes in Scotland: bringing health services back in. Soc Sci Med 2005; 60(7): 1423-1435.

22. NHS. NHS atlas of variation in healthcare. 2011. http://uww.rightcare.nhs.uk/ index.php/nhs-atlas/ laccessed 5 Nov 2015).

23. Shaw RL, Booth A, Sutton AJ, et al. Finding qualitative research: an evaluation of search strategies. BMC Med Res Methodol 2004; 4: 5.

24. World Health Organization. WHO expert committee on diabetes mellitus. Second report. Technical Report Series 646. Geneva: WHO, 1980.

25. National Audit Office. The management of adult diabetes services in the NHS. 2012. http://www.nao.org.uk/publications/1213/adult_diabetes_services.aspx laccessed 5 Nov 2015).

26. Cane J, O'Connor D, Michie S. Validation of the theoretical domains framework for use in behaviour change and implementation research. Implement Sci 2012; 7: 37

27. Michie S, Johnston M, Abraham C, et al. Making psychological theory useful for implementing evidence based practice: a consensus approach. Qual Saf Health Care 2005; 14(1): 26-33
28. Tavender EJ, Bosch M, Gruen RL, et al. Understanding practice: the factors that influence management of mild traumatic brain injury in the emergency department - a qualitative study using the Theoretical Domains Framework Implement Sci 2014; 9: 8

29. National Institute for Health and Care Excellence. The guidelines manual. January 2009. Appendix I: methodology checklist: qualitative studies. London: NICE, 2009

30. Lee YK, Lee PY, Ng CJ. A qualitative study on healthcare professionals' perceived barriers to insulin initiation in a multi-ethnic population. BMC Fam Pract 2012; 13: 28

31. Lee PY, Lee YK, Khoo EM, Ng CJ. How do health care professionals assess patients when initiating insulin therapy? A qualitative study. Prim Care Diabetes 2014; 8(1): 49-55.

32. Noor Abdulhadi NM, Al-Shafaee MA, Wahlström R, Hjelm K. Doctors' and nurses views on patient care for type 2 diabetes: an interview study in primary health care in Oman. Prim Health Care Res Dev 2013; 14(3): 258-269.

33. Agarwal G, Nair K, Cosby J, et al. GPs' approach to insulin prescribing in older patients: a qualitative study. Br J Gen Pract 2008; 58(553): 569-575.

34. Pooley CG, Gerrard C, Hollis S, et al. 'Oh it's a wonderful practice ... you can talk to them': a qualitative study of patients' and health professionals' views on the management of type 2 diabetes. Health Soc Care Community 2001; 9(5): 318-326.

35. Stewart J, Dyas J, Brown K, Kendrick D. Achieving blood pressure targets: lessons from a study with practice nurses. J Diabetes Nurs 2006; 10(5): 186-193.

36. Howard JA, Bower K, Putnam W. Factors influencing the management of hypertension in type 2 diabetes. Can J Diabetes 2006; 30(1): 38-45.

37. Crosson JC, Heisler M, Subramanian U, et al. Physicians' perceptions of barriers to cardiovascular disease risk factor control among patients with diabetes: results from the translating research into action for diabetes (TRIAD) study. J Am Board Fam Med 2010; 23(2): 171-178.

38. Ab E, Denig P, van Vliet T, Dekker JH. Reasons of general practitioners for not prescribing lipid-lowering medication to patients with diabetes: a qualitative study. BMC Fam Pract 2009; 10: 24.

39. Haque M, Emerson SH, Dennison CR, et al. Barriers to initiating insulin therapy in patients with type 2 diabetes mellitus in public-sector primary health care centres in Cape Town. S Afr Med J 2005; 95(10): 798-802

40. Larme AC, Pugh JA. Attitudes of primary care providers toward diabetes: barriers to guideline implementation. Diabetes Care 1998; 21(9): 1391-1396.

41. Abbott S, Burns J, Gleadell A, Gunnell C. Community nurses and selfmanagement of blood glucose. Br J Community Nurs 2007; 12(1): 6-11.

42. Jeavons D. Hungin AP, Cornford CS. Patients with poorly controlled diabetes in primary care: healthcare clinicians' beliefs and attitudes. Postgrad Med J 2006; 82(967): 347-350.

43. Greaves CJ, Brown P, Terry RT, et al. Converting to insulin in primary care: an exploration of the needs of practice nurses. J Adv Nurs 2003; 42(5): 487-496.

44. Burden ML, Burden AC. Attitudes to starting insulin in primary care. Practical Diabetes International 2007; 24(7): 346-350.

45. Wens J, Vermeire E, Van Royen P, et al. GPs' perspectives of type 2 diabetes patients' adherence to treatment: a qualitative analysis of barriers and solutions. BMC Fam Pract 2005; 6(1): 20

46. Fhärm E, Rolandsson O, Johansson EE. 'Aiming for the stars': GPs' dilemmas in the prevention of cardiovascular disease in type 2 diabetes patients: focus group interviews. Fam Pract 2009; 26(2): 109-114.

47. Brown JB, Harris SB, Webster-Bogaert S, et al. The role of patient, physician and systemic factors in the management of type 2 diabetes mellitus. Fam Pract 2002; 19(4): 344-349.

48. Daniels A, Biesma R, Otten J, et al. Ambivalence of primary health care professionals towards the South African guidelines for hypertension and diabetes. S Afr Med J 2000; 90(12): 1206-1211.

49. Alberti H, Boudriga N, Nabli M. Primary care management of diabetes in a low/middle income country: a multi-method, qualitative study of barriers and facilitators to care. BMC Fam Pract 2007; 8: 63

50. Grant RW, Lutfey KE, Gerstenberger E, et al. The decision to intensify therapy in patients with type 2 diabetes: results from an experiment using a clinical case vignette. J Am Board Fam Med 2009; 22(5): 513-520.

51. Raaijmakers LG, Hamers FJ, Martens MK, et al. Perceived facilitators and barriers in diabetes care: a qualitative study among health care professionals in the Netherlands. BMC Fam Pract 2013; 14: 114.

52. Kern DH, Mainous AG 3rd. Disease management for diabetes among family 
physicians and general internists: opportunism or planned care? Fam Med 2001; 33(8): $621-625$.

53. Elliott DJ, Robinson EJ, Sanford M, et al. Systemic barriers to diabetes management in primary care: a qualitative analysis of Delaware physicians. Am J Med Qual 2011; 26(4): 284-290.

54. O'Connor R, Mannix M, Mullen J, et al. Structured care of diabetes in general practice: a qualitative study of the barriers and facilitators. Ir Med J 2013; 106(3): $77-80$

55. McHugh S, O'Mullane M, Perry IJ, Bradley C. Barriers to, and facilitators in, introducing integrated diabetes care in Ireland: a qualitative study of views in general practice. BMJ Open 2013; 3(8): e003217.

56. Trewin VF, Veitch GB, Lawrence CJ. Influences on GP prescribing habits: any hypoglycaemic for the elderly? Pharm J 1999; 262(7039): 482-484

57. Manski-Nankervis JA, Furler J, Blackberry I, et al. Roles and relationships between health professionals involved in insulin initiation for people with type 2 diabetes in the general practice setting: a qualitative study drawing on relational coordination theory. BMC Fam Pract 2014; 15: 20

58. Tan AM, Muthusamy L, Ng CC, et al. Initiation of insulin for type 2 diabetes mellitus patients: what are the issues? A qualitative study. Singapore Med J 2011; 52(11): 801-809

59. Furler J, Spitzer O, Young D, Best J. Insulin in general practice: barriers and enablers for timely initiation. Aust Fam Physician 2011; 40(8): 617-621.

60. Halifax NV, Cafazzo JA, Irvine MJ, et al. Telemanagement of hypertension: a qualitative assessment of patient and physician preferences. Can J Cardiol 2007; 23(7): 591-594.

61. Loewe R, Freeman J. Interpreting diabetes mellitus: differences between patient and provider models of disease and their implications for clinical practice. Cult Med Psychiatry 2000; 24(4): 379-401.

62. Kirsh S, Hein M, Pogach L, et al. Improving outpatient diabetes care. Am J Med Qual 2012; 27(3): 233-240

63. Grol R, Wensing M, Eccles M, Davis D, eds. Improving patient care: the implementation of change in health care. Chichester: Wiley-Blackwell, 2013.

64. Glenton C, Colvin CJ, Carlsen B, et al. Barriers and facilitators to the implementation of lay health worker programmes to improve access to maternal and child health: qualitative evidence synthesis. Cochrane Database Syst Rev 2013; (10): CD010414.

65. PRISMA. Transparent reporting of systematic reviews and meta-analyses. http:// unw.prisma-statement.org/ (accessed 5 Jan 2016).

66. Michie S, van Stralen MM, West R. The behaviour change wheel: a new method for characterising and designing behaviour change interventions. Implement $\mathrm{SC}$ 2011; 6: 42.

67. Michie S, Johnston M, Francis J, et al. From theory to intervention: mapping theoretically derived behavioural determinants to behaviour change techniques. Applied Psychology 2008; 57(4): 660-680.

68. van Bokhoven MA, Kok G, van der Weijden T. Designing a quality improvement intervention: a systematic approach. Qual Saf Health Care 2003; 12(3): 215-220.

69. Nam S, Chesla C, Stotts NA, et al. Barriers to diabetes management: patient and provider factors. Diabetes Res Clin Pract 2011; 93(1): 1-9.

70. von Arx LB, Kjaer T. The patient perspective of diabetes care: a systematic review of stated preference research. Patient 2014; 7(3): 283-300.

71. Ferlie EB, Shortell SM. Improving the quality of health care in the United Kingdom and the United States: a framework for change. Milbank Q2001; 79(2): 281-315.

72. Ivers NM, Sales A, Colquhoun $\mathrm{H}$, et al. No more 'business as usual' with audit and feedback interventions: towards an agenda for a reinvigorated intervention. Implement Sci2014; 9: 14.

73. Improved Clinical Effectiveness through Behavioural Research Group. Designing theoretically-informed implementation interventions. Implement Sci2006; 1: 4.

74. Khunti K, Gray LJ, Skinner T, et al. Effectiveness of a diabetes education and self management programme (DESMOND) for people with newly diagnosed type 2 diabetes mellitus: three year follow-up of a cluster randomised controlled trial in primary care. BMJ 2012; 344: e2333.

75. Dyson J, Lawton R, Jackson C, Cheater F. Does the use of a theoretical approach tell us more about hand hygiene behaviour? The barriers and levers to hand hygiene. J Infect Prev 2011; 12(1): 17-24.

76. McSherry LA, Dombrowski SU, Francis JJ, et al. 'It's a can of worms': understanding primary care practitioners' behaviours in relation to HPV using the Theoretical Domains Framework. Implement Sci 2012; 7: 73.

77. Lugtenberg M, Zegers-van Schaick JM, Westert GP, Burgers JS. Why don't physicians adhere to guideline recommendations in practice? An analysis of barriers among Dutch general practitioners. Implement Sci 2009; 4: 54.

78. Presseau J, Ivers NM, Newham JJ, et al. Using a behaviour change techniques taxonomy to identify active ingredients within trials of implementation interventions for diabetes care. Implement Sci2015; 10: 55. 


\section{Appendix 1. Summary of included studies}

\begin{tabular}{|c|c|c|c|c|c|}
\hline $\begin{array}{l}\text { Study and year } \\
\text { published } \\
\text { (continent) }\end{array}$ & Study aims & $\begin{array}{l}\text { Data collection } \\
\text { method }\end{array}$ & Inclusion criteria & Participants & $\begin{array}{l}\text { Clinical targets } \\
\text { studied }\end{array}$ \\
\hline $\begin{array}{l}\text { Lee }^{30} 2012 \text { (Asia) } \\
\text { Note: Lee } 2012 \text { and } \\
\text { Lee } 2014 \text { report } \\
\text { different data from } \\
\text { the same study }\end{array}$ & $\begin{array}{l}\text { To identify barriers to insulin } \\
\text { initiation from the healthcare } \\
\text { professionals' perspective }\end{array}$ & $\begin{array}{l}\text { Focus groups } \\
\text { and interviews }\end{array}$ & $\begin{array}{l}\text { Healthcare professionals providing } \\
\text { diabetes care and involved in insulin } \\
\text { initiation in } 3 \text { primary care healthcare } \\
\text { settings in Malaysia }\end{array}$ & $\begin{array}{l}38 \text { healthcare professionals, } 28 \text { of } \\
\text { whom were identified as primary care } \\
\text { physicians }\end{array}$ & $\begin{array}{l}\text { Glycaemic } \\
\text { control: } \\
\text { initiation of } \\
\text { insulin }\end{array}$ \\
\hline $\begin{array}{l}\text { Lee }^{31} 2014 \text { (Asia) } \\
\text { Note: Lee } 2012 \text { and } \\
\text { Lee } 2014 \text { report } \\
\text { different data from } \\
\text { the same study }\end{array}$ & $\begin{array}{l}\text { To explore how healthcare } \\
\text { professionals assess patients } \\
\text { when initiating insulin therapy in } \\
\text { type } 2 \text { diabetes }\end{array}$ & $\begin{array}{l}\text { Semi-structured } \\
\text { interviews and } \\
\text { focus groups }\end{array}$ & $\begin{array}{l}\text { Healthcare professionals and other } \\
\text { stakeholders who were involved } \\
\text { in insulin initiation in primary and } \\
\text { secondary care }\end{array}$ & $\begin{array}{l}36 \text { healthcare professionals ( } 12 \\
\text { family physicians; } 10 \text { family medicine } \\
\text { specialists; } 8 \text { medical officers; } 3 \text { diabetes } \\
\text { nurse educators; } 2 \text { endocrinologists; } \\
1 \text { pharmacist); and } 5 \text { government } \\
\text { policymakers. }\end{array}$ & $\begin{array}{l}\text { Glycaemic } \\
\text { control: } \\
\text { initiation of } \\
\text { insulin }\end{array}$ \\
\hline $\begin{array}{l}\text { Greaves }^{43} 2003 \\
\text { (Europe; UK) }\end{array}$ & $\begin{array}{l}\text { To explore the views of primary } \\
\text { care nurses about converting } \\
\text { patients with diabetes from oral } \\
\text { hyperglycaemic [sic] agents to } \\
\text { injected insulin within primary } \\
\text { care }\end{array}$ & $\begin{array}{l}\text { Semi-structured } \\
\text { interviews }\end{array}$ & $\begin{array}{l}\text { Primary care nurses with responsibility } \\
\text { for diabetes care }\end{array}$ & $\begin{array}{l}25 \text { primary care nurses, } 18 \text { of these from } \\
\text { a diabetes special interest group. Years } \\
\text { qualified } 27.2 \text { (SD } 6.8 ; \text { range } 13-39) ; \\
\text { years as practice nurse } 12(5.8 ; 4-25)\end{array}$ & $\begin{array}{l}\text { Glycaemic } \\
\text { control: } \\
\text { initiation of } \\
\text { insulin }\end{array}$ \\
\hline $\begin{array}{l}\text { Noor Abdulhadi32 } \\
2013 \text { (Asia) }\end{array}$ & $\begin{array}{l}\text { To explore primary healthcare } \\
\text { providers' experience of } \\
\text { encounters with patients with } \\
\text { type } 2 \text { diabetes mellitus and their } \\
\text { preferences and suggestions for } \\
\text { future improvement of diabetes } \\
\text { care }\end{array}$ & $\begin{array}{l}\text { Semi-structured } \\
\text { interviews }\end{array}$ & $\begin{array}{l}\text { Primary care physicians and nurses } \\
\text { working at a primary healthcare } \\
\text { centre who had participated in an } \\
\text { observational study }\end{array}$ & $\begin{array}{l}19 \text { primary care physicians and } 7 \\
\text { primary care nurses; age range } \\
25-55 \text { years }\end{array}$ & General \\
\hline $\begin{array}{l}\text { Agarwal }^{33} 2008 \\
\text { (North America) }\end{array}$ & $\begin{array}{l}\text { To explore the process and } \\
\text { rationale for prescribing decisions } \\
\text { of primary care physicians when } \\
\text { treating older patients with type } \\
2 \text { diabetes }\end{array}$ & Interviews & $\begin{array}{l}\text { Primary care physicians actively } \\
\text { practising within a 1-hour drive of a } \\
\text { large suburban city in Ontario, Canada }\end{array}$ & 21 primary care physicians & $\begin{array}{l}\text { Glycaemic } \\
\text { control: } \\
\text { prescribing } \\
\text { insulin }\end{array}$ \\
\hline $\begin{array}{l}\text { Pooley }{ }^{34} 2001 \\
\text { (Europe; UK) }\end{array}$ & $\begin{array}{l}\text { To explore the issues that patients } \\
\text { and doctors perceive as central to } \\
\text { effective management of diabetes } \\
\text { with particular attention to the } \\
\text { nature of the patient-practitioner } \\
\text { relationship }\end{array}$ & Interviews & $\begin{array}{l}\text { Health professionals: from } 4 \text { localities } \\
\text { within } 2 \text { health authorities in North } \\
\text { West England, UK, who had signalled } \\
\text { their willingness to participate on a } \\
\text { previous questionnaire }\end{array}$ & $\begin{array}{l}\text { Healthcare professionals: } 7 \text { primary care } \\
\text { physicians, } 9 \text { primary care nurses, } 9 \\
\text { diabetes nurse specialists, } 3 \text { community } \\
\text { nurses, } 5 \text { dieticians, } 4 \text { chiropodists, } \\
3 \text { optometrists, } 2 \text { diabetes specialist } \\
\text { physicians }\end{array}$ & General \\
\hline $\begin{array}{l}\text { Brown }{ }^{47} 2002 \text { (North } \\
\text { America) } \\
\end{array}$ & $\begin{array}{l}\text { To explore primary care } \\
\text { physicians' perceptions of the } \\
\text { barriers and facilitators to the } \\
\text { management of patients with type } \\
2 \text { diabetes mellitus }\end{array}$ & Focus groups & $\begin{array}{l}\text { Primary care physicians participating } \\
\text { in simultaneous quantitative study on } \\
\text { the management of type } 2 \text { diabetes } \\
\text { mellitus }\end{array}$ & $\begin{array}{l}30 \text { primary care physicians; age not } \\
\text { recorded but average years since } \\
\text { graduation } 18.7 \text { (range 4-35); sex (M:F) } \\
\text { 16:14 }\end{array}$ & General \\
\hline $\begin{array}{l}\text { Stewart }{ }^{35} 2006 \\
\text { (Europe; UK) }\end{array}$ & $\begin{array}{l}\text { To explore whether and how } \\
\text { practice nurses discuss blood } \\
\text { pressure targets and beliefs } \\
\text { about the barriers to achieving } \\
\text { target blood pressure in patients } \\
\text { with diabetes }\end{array}$ & $\begin{array}{l}\text { Semi-structured } \\
\text { interviews }\end{array}$ & $\begin{array}{l}\text { Primary care nurses responsible } \\
\text { for providing most of the diabetes } \\
\text { care in practices taking part in a } \\
\text { trial to improve blood pressure in } \\
\text { type } 2 \text { diabetes mellitus patients in } \\
\text { Nottingham, UK }\end{array}$ & 43 primary care nurses & Blood pressure \\
\hline $\begin{array}{l}\text { Howard }{ }^{36} 2006 \\
\text { (North America) }\end{array}$ & $\begin{array}{l}\text { To investigate the factors that } \\
\text { influence the management of } \\
\text { hypertension in patients with } \\
\text { type } 2 \text { diabetes }\end{array}$ & $\begin{array}{l}\text { Interviews } \\
\text { (for qualitative } \\
\text { element) }\end{array}$ & $\begin{array}{l}\text { Physicians and patients from } 2 \text { primary } \\
\text { care medical centres in Halifax, } \\
\text { Canada }\end{array}$ & 5 primary care physicians (and 7 patients) & Blood pressure \\
\hline $\begin{array}{l}\text { Crosson }^{37} 2010 \\
\text { (North Americal) }\end{array}$ & $\begin{array}{l}\text { To explore what primary care } \\
\text { physicians perceive to be barriers } \\
\text { to good cardiovascular disease } \\
\text { risk factor control in those with } \\
\text { diabetes and hypertension and } \\
\text { high cholesterol }\end{array}$ & Interviews & $\begin{array}{l}\text { Primary care physicians in } 4 \text { states } \\
\text { in US caring for patients with diabetes } \\
\text { in a variety of practice environments } \\
\text { (solo, group practice, integrated } \\
\text { healthcare delivery system) }\end{array}$ & 34 primary care physicians & $\begin{array}{l}\text { General: with } \\
\text { an interest in } \\
\text { cardiovascular } \\
\text { disease risk } \\
\text { factor control }\end{array}$ \\
\hline $\begin{array}{l}\mathrm{Ab}^{38} 2009 \text { (Europe; } \\
\text { non-UK) }\end{array}$ & $\begin{array}{l}\text { To determine factors underlying } \\
\text { primary care physicians' decisions } \\
\text { not to prescribe lipid-lowering } \\
\text { drugs to patients with type } 2 \\
\text { diabetes }\end{array}$ & $\begin{array}{l}\text { Semi-structured } \\
\text { interviews }\end{array}$ & $\begin{array}{l}\text { Primary care physicians in a region of } \\
\text { the north of the Netherlands, where } \\
\text { a guideline on the use of statins in } \\
\text { diabetes had been distributed, who } \\
\text { indicated they were familiar with the } \\
\text { guideline }\end{array}$ & 7 primary care physicians & $\begin{array}{l}\text { Cholesterol } \\
\text { control: } \\
\text { prescribing } \\
\text { lipid-lowering } \\
\text { drugs }\end{array}$ \\
\hline $\begin{array}{l}\text { Haque }^{39} 2005 \\
\text { (Africa) }\end{array}$ & $\begin{array}{l}\text { To examine barriers to initiating } \\
\text { insulin therapy in patients with } \\
\text { poorly controlled type } 2 \text { diabetes } \\
\text { on maximum oral glucose- } \\
\text { lowering agents }\end{array}$ & $\begin{array}{l}\text { Focus groups } \\
\text { and semi- } \\
\text { structured } \\
\text { interviews }\end{array}$ & $\begin{array}{l}\text { Primary care physicians at one } \\
\text { community health centre in the } \\
\text { Western Cape }\end{array}$ & $\begin{array}{l}46 \text { primary care physicians working at } \\
4 \text { primary care community health } \\
\text { centres in Cape Town district }\end{array}$ & $\begin{array}{l}\text { Glycaemic } \\
\text { control: } \\
\text { initiation of } \\
\text { insulin }\end{array}$ \\
\hline
\end{tabular}




\section{Appendix 1 continued. Summary of included studies}

\begin{tabular}{|c|c|c|c|c|c|}
\hline $\begin{array}{l}\text { Study and year } \\
\text { published } \\
\text { (continent) }\end{array}$ & Study aims & $\begin{array}{l}\text { Data collection } \\
\text { method }\end{array}$ & Inclusion criteria & Participants & $\begin{array}{l}\text { Clinical targets } \\
\text { studied }\end{array}$ \\
\hline $\begin{array}{l}\text { Larme } 401998 \text { (North } \\
\text { America) }\end{array}$ & $\begin{array}{l}\text { To explore how attitudes } \\
\text { rather than knowledge may } \\
\text { impede primary care providers' } \\
\text { adherence to standards of care } \\
\text { in diabetes }\end{array}$ & $\begin{array}{l}\text { Interviews } \\
\text { (for qualitative } \\
\text { element) }\end{array}$ & $\begin{array}{l}\text { Primary care providers attending } \\
\text { a continuing medical education } \\
\text { programme on diabetes }\end{array}$ & $\begin{array}{l}31 \text { healthcare professionals: } 24 \text { primary } \\
\text { care physicians, } 2 \text { primary care nurses, } \\
\text { and } 5 \text { physician assistants; age range } \\
27-58 \text { years; sex (M:F) 23:8 }\end{array}$ & General \\
\hline $\begin{array}{l}\text { Fhärm }{ }^{46} 2009 \\
\text { (Europe; non-UK) }\end{array}$ & $\begin{array}{l}\text { To explore primary care } \\
\text { physicians' experiences regarding } \\
\text { treatment practice in type } 2 \\
\text { diabetes with specific focus on } \\
\text { the prevention of cardiovascular } \\
\text { disease }\end{array}$ & Focus groups & $\begin{array}{l}\text { Experienced primary care physicians } \\
\text { from the County of Västerbotten, } \\
\text { Sweden, with patients with type } 2 \\
\text { diabetes in their practice }\end{array}$ & $\begin{array}{l}14 \text { primary care physicians from } 9 \text { group } \\
\text { practices; sex (M:F) 6:8; age median } \\
54 \text { years, range } 43-64 ; \text { years since } \\
\text { medical degree } 24 \text { (10-36); rural:urban } \\
\text { practice } 5: 9\end{array}$ & $\begin{array}{l}\text { General: } \\
\text { with an } \\
\text { interest in the } \\
\text { prevention of } \\
\text { cardiovascular } \\
\text { disease }\end{array}$ \\
\hline $\begin{array}{l}\text { Abbott¹ } 2007 \\
\text { (Europe; UK) }\end{array}$ & $\begin{array}{l}\text { To examine the perceived } \\
\text { purposes and functions of self- } \\
\text { testing (self-monitoring of blood } \\
\text { glucose) as understood by nurses } \\
\text { who treat/manage type } 2 \text { diabetes } \\
\text { in primary care settings }\end{array}$ & $\begin{array}{l}\text { Semi-structured } \\
\text { interviews }\end{array}$ & $\begin{array}{l}\text { Nurses working in community and } \\
\text { primary care in Essex, UK }\end{array}$ & 7 nurses & $\begin{array}{l}\text { Glycaemic } \\
\text { control: self- } \\
\text { monitoring of } \\
\text { blood glucose }\end{array}$ \\
\hline $\begin{array}{l}\text { Jeavons }{ }^{42} 2006 \\
\text { (Europe; UK) }\end{array}$ & $\begin{array}{l}\text { To investigate doctors' and } \\
\text { nurses' views about treating } \\
\text { patients with type } 2 \text { diabetes with } \\
\text { unacceptable glycaemic control } \\
\text { receiving maximal oral treatment }\end{array}$ & Focus groups & $\begin{array}{l}\text { One primary care physician from each } \\
\text { practice in the local health authority; } \\
\text { all primary care physician trainers } \\
\text { with the local training scheme; and } \\
\text { one practice nurse from each practice } \\
\text { attending meetings as part of a local } \\
\text { practice nurse support group }\end{array}$ & $\begin{array}{l}15 \text { primary care physicians, } 8 \text { primary } \\
\text { care nurses. Years qualified: physicians } \\
\text { 12-41; nurses 6-28. Sex: physicians } \\
\text { (M:F) 11:4; nurses 0:8 }\end{array}$ & $\begin{array}{l}\text { Glycaemic } \\
\text { control: } \\
\text { initiation of } \\
\text { insulin }\end{array}$ \\
\hline $\begin{array}{l}\text { Wens }{ }^{45} 2005 \\
\text { (Europe; non-UK) }\end{array}$ & $\begin{array}{l}\text { To identify primary care } \\
\text { physicians' thoughts and feelings } \\
\text { about type } 2 \text { diabetes patients' } \\
\text { adherence to treatment }\end{array}$ & Focus groups & $\begin{array}{l}\text { All primary care physicians in one } \\
\text { Belgian municipality }\end{array}$ & $\begin{array}{l}40 \text { primary care physicians; mean age } \\
45.3 \text { years ( } 10.5 \text { SD); sex (M:F) 26:14 }\end{array}$ & General \\
\hline $\begin{array}{l}\text { Burden }^{44} 2007 \\
\text { (Europe; UK) }\end{array}$ & $\begin{array}{l}\text { To measure the attitudes of } \\
\text { patients, primary care physicians, } \\
\text { and nurses when starting insulin } \\
\text { in people with type } 2 \text { diabetes in } \\
\text { primary care }\end{array}$ & $\begin{array}{l}\text { Focus groups } \\
\text { followed by } \\
\text { plenary session } \\
\text { and interviews }\end{array}$ & $\begin{array}{l}\text { For qualitative element: primary care } \\
\text { physicians and nurses in two cohorts } \\
\text { who completed the Insulin for Life } \\
\text { training course on initiating insulin }\end{array}$ & $\begin{array}{l}37 \text { primary care physicians and nurses } \\
\text { (numbers of each not specified) }\end{array}$ & $\begin{array}{l}\text { Glycaemic } \\
\text { control: } \\
\text { initiation of } \\
\text { insulin }\end{array}$ \\
\hline $\begin{array}{l}\text { Alberti49 } 2007 \\
\text { (Africa) }\end{array}$ & $\begin{array}{l}\text { To discover the main barriers } \\
\text { and facilitators to care in the } \\
\text { management of diabetes in } \\
\text { primary care in a low/middle } \\
\text { income country }\end{array}$ & $\begin{array}{l}\text { Observation, } \\
\text { focus groups, } \\
\text { and interviews }\end{array}$ & $\begin{array}{l}\text { Health professionals lincluding } \\
\text { physicians and nurses) providing } \\
\text { diabetes care in public sector primary } \\
\text { care centres in Tunisia and patients } \\
\text { with diabetes }\end{array}$ & $\begin{array}{l}3 \text { health centres: staff and patients } \\
\text { (observation); lead physician plus } 7 \text { key } \\
\text { informants (interview); } 4 \text { paramedical } \\
\text { staff groups and } 12 \text { patient groups (focus } \\
\text { groups); also visits to } 48 \text { other health } \\
\text { centres; attendees at } 19 \text { meetings; and } \\
\text { discussions with staff in government } \\
\text { departments }\end{array}$ & General \\
\hline $\begin{array}{l}\text { Daniels }^{48} 2000 \\
\text { (Africa) }\end{array}$ & $\begin{array}{l}\text { To audit the responses of } \\
\text { health professionals in primary } \\
\text { care to receipt of diabetes and } \\
\text { hypertension guidelines and } \\
\text { to determine their attitudes to } \\
\text { implementation }\end{array}$ & $\begin{array}{l}\text { Focus groups } \\
\text { and in-depth } \\
\text { discussions } \\
\text { at first site; } \\
\text { semi-structured } \\
\text { interviews at } \\
\text { other } 3 \text { sites; } \\
\text { and clinical } \\
\text { observation at } \\
3 \text { sites }\end{array}$ & $\begin{array}{l}\text { Healthcare professionals working } \\
\text { at community health centres in the } \\
\text { Western Cape }\end{array}$ & $\begin{array}{l}15 \text { physicians and } 10 \text { nurses at } 4 \\
\text { community health centres }\end{array}$ & General \\
\hline $\begin{array}{l}\text { Grant }^{50} 2009 \\
\text { (North America) }\end{array}$ & $\begin{array}{l}\text { To assess whether patient or } \\
\text { physician demographic } \\
\text { variables influence the decision to } \\
\text { intensify therapy in patients with } \\
\text { type } 2 \text { diabetes }\end{array}$ & $\begin{array}{l}\text { Structured } \\
\text { interviews (for } \\
\text { qualitative } \\
\text { element of study) }\end{array}$ & $\begin{array}{l}\text { Primary care physicians active in } \\
\text { clinical care more than half the time } \\
\text { and practising in New Jersey, New } \\
\text { York, or Pennsylvania, with } \leq 12 \text { years } \\
\text { or } \geq 22 \text { years clinical experience and } \\
\text { trained in accredited US medical } \\
\text { schools }\end{array}$ & 192 primary care physicians & $\begin{array}{l}\text { General: with } \\
\text { an interest in } \\
\text { medication } \\
\text { intensification }\end{array}$ \\
\hline $\begin{array}{l}\text { Halifax }{ }^{60} 2007 \text { (North } \\
\text { America) }\end{array}$ & $\begin{array}{l}\text { To review telemedicine as } \\
\text { it pertains to hypertension } \\
\text { management and to outline } \\
\text { experiences in developing a new } \\
\text { telemedicine system }\end{array}$ & Focus groups & $\begin{array}{l}\text { Primary care physicians with active } \\
\text { clinical practice with English-speaking } \\
\text { patients who had type } 2 \text { diabetes and } \\
\text { hypertension }\end{array}$ & 24 primary care physicians & Blood pressure \\
\hline $\begin{array}{l}\text { Kern }{ }^{52} 2001 \text { (North } \\
\text { America) }\end{array}$ & $\begin{array}{l}\text { To explore primary care providers' } \\
\text { perceived barriers to the delivery } \\
\text { of diabetes care }\end{array}$ & $\begin{array}{l}\text { Semi-structured } \\
\text { interviews }\end{array}$ & $\begin{array}{l}\text { Primary care physicians from } \\
\text { practices with a relatively high } \\
\text { proportion of patients with diabetes }\end{array}$ & 12 primary care physicians & General \\
\hline
\end{tabular}




\begin{tabular}{|c|c|c|c|c|c|}
\hline $\begin{array}{l}\text { Study and year } \\
\text { published } \\
\text { (continent) }\end{array}$ & Study aims & $\begin{array}{l}\text { Data collection } \\
\text { method }\end{array}$ & Inclusion criteria & Participants & $\begin{array}{l}\text { Clinical targets } \\
\text { studied }\end{array}$ \\
\hline $\begin{array}{l}\text { Kirsh }{ }^{62} 2010 \text { (North } \\
\text { America) }\end{array}$ & $\begin{array}{l}\text { To identify best practices in } \\
\text { outpatient diabetes and the } \\
\text { factors associated with their } \\
\text { development }\end{array}$ & $\begin{array}{l}\text { Telephone } \\
\text { interviews }\end{array}$ & Primary care diabetes clinic sites & $\begin{array}{l}\text { One or more informant/s from each of } \\
31 \text { sites: primary care clinic directors; } \\
\text { primary care physicians and nurse } \\
\text { practitioners; nurse managers; and } \\
\text { clinical pharmacists }\end{array}$ & General \\
\hline $\begin{array}{l}\text { Loewe }^{61} 2000 \text { (North } \\
\text { America) }\end{array}$ & $\begin{array}{l}\text { To explore the different frames } \\
\text { or explanatory models that } \\
\text { physicians and patients use to } \\
\text { understand diabetes }\end{array}$ & $\begin{array}{l}\text { Semi-structured } \\
\text { interviews and } \\
\text { participant } \\
\text { observation }\end{array}$ & $\begin{array}{l}\text { Healthcare professionals and patients } \\
\text { with diabetes at } 1 \text { of } 2 \text { family practice } \\
\text { training sites in Chicago, US }\end{array}$ & $\begin{array}{l}17 \text { healthcare professionals: } 12 \text { primary } \\
\text { care physicians; others: } 1 \text { medical } \\
\text { student, } 1 \text { physician assistant, } 3 \\
\text { attending physicians (and } 22 \text { patients } \\
\text { with diabetes) }\end{array}$ & General \\
\hline $\begin{array}{l}\text { Raaijmakers }{ }^{51} 2013 \\
\text { (Europe; non-UK) }\end{array}$ & $\begin{array}{l}\text { To investigate the facilitating } \\
\text { and impeding factors among } \\
\text { healthcare professionals in } \\
\text { diabetes care }\end{array}$ & $\begin{array}{l}\text { Semi-structured } \\
\text { interviews }\end{array}$ & $\begin{array}{l}\text { Healthcare professionals with a } \\
\text { primary role in diabetes care }\end{array}$ & $\begin{array}{l}18 \text { healthcare professionals in total } \\
\text { comprising: } 3 \text { primary care physicians, } \\
3 \text { primary care nurses, } 1 \text { primary care } \\
\text { diabetes nurse lothers: non-primary } \\
\text { care diabetes nurse, dieticians, physical } \\
\text { therapists, internal medicine physicians, } \\
\text { pharmacistt. Of all 18: mean age } \\
44 \text { years (range 31-59); sex (M:F) 7:11 }\end{array}$ & General \\
\hline $\begin{array}{l}\text { Trewin } 561999 \\
\text { (Europe; UK) }\end{array}$ & $\begin{array}{l}\text { To investigate a suite of presumed } \\
\text { influences on primary care } \\
\text { physician prescribing practice }\end{array}$ & $\begin{array}{l}\text { Structured } \\
\text { interviews }\end{array}$ & $\begin{array}{l}\text { Primary care physicians working in } \\
\text { Devon in UK }\end{array}$ & 20 primary care physicians & $\begin{array}{l}\text { Glycaemic } \\
\text { control }\end{array}$ \\
\hline $\begin{array}{l}\text { Manski-Nankervis }{ }^{57} \\
2014 \text { (Australia and } \\
\text { Oceania) }\end{array}$ & $\begin{array}{l}\text { To explore roles and relationships } \\
\text { between health professionals } \\
\text { involved in insulin initiation }\end{array}$ & $\begin{array}{l}\text { Interviews (face- } \\
\text { to-face and by } \\
\text { telephone) }\end{array}$ & $\begin{array}{l}\text { Purposely selected from responders } \\
\text { to previous survey in Australia in } \\
\text { which relational coordination between } \\
\text { health professionals involved in insulin } \\
\text { initiation was measured }\end{array}$ & $\begin{array}{l}21 \text { healthcare professionals: } 5 \text { primary } \\
\text { care physicians; } 5 \text { primary care nurses; } \\
5 \text { diabetes nurse educators; } 6 \text { hospital } \\
\text { physicians }\end{array}$ & $\begin{array}{l}\text { Glycaemic } \\
\text { control: } \\
\text { initiation of } \\
\text { insulin }\end{array}$ \\
\hline $\operatorname{Tan}^{58} 2011$ (Asia) & $\begin{array}{l}\text { To determine the issues relating } \\
\text { to insulin initiation for patients } \\
\text { with diabetes managed in primary } \\
\text { care polyclinics in Singapore }\end{array}$ & Focus groups & $\begin{array}{l}\text { Physicians and nurses working in } \\
\text { primary care polyclinics in Singapore } \\
\text { and patients with type } 2 \text { diabetes } \\
\text { mellitus }\end{array}$ & 8 physicians; 10 nurses; and 11 patients & $\begin{array}{l}\text { Glycaemic } \\
\text { control: } \\
\text { initiation of } \\
\text { insulin }\end{array}$ \\
\hline $\begin{array}{l}\text { Furler"59 } 2011 \\
\text { (Australia and } \\
\text { Oceania) }\end{array}$ & $\begin{array}{l}\text { To explore the views of family } \\
\text { physicians, diabetes nurse } \\
\text { educators, and patients about } \\
\text { starting insulin in primary care }\end{array}$ & $\begin{array}{l}\text { Semi-structured } \\
\text { interviews }\end{array}$ & $\begin{array}{l}\text { Primary care physicians, diabetes } \\
\text { nurse educators with experience of } \\
\text { primary care, and patients who had } \\
\text { recently commenced insulin or on } \\
\text { maximum oral therapy }\end{array}$ & $\begin{array}{l}10 \text { family physicians; } 4 \text { diabetes nurse } \\
\text { educators; and } 12 \text { patients }\end{array}$ & $\begin{array}{l}\text { Glycaemic } \\
\text { control: } \\
\text { initiation of } \\
\text { insulin }\end{array}$ \\
\hline $\begin{array}{l}\text { Elliott }{ }^{53} 2011 \text { (North } \\
\text { America) }\end{array}$ & $\begin{array}{l}\text { To identify the systemic barriers } \\
\text { to primary care diabetes } \\
\text { management in the small office } \\
\text { setting in Delaware }\end{array}$ & Focus groups & Primary care physicians in Delaware & $\begin{array}{l}25 \text { physicians: } 21 \text { primary care } \\
\text { physicians and } 4 \text { specialists with an } \\
\text { interest in primary care management } \\
\text { of diabetes }\end{array}$ & General \\
\hline $\begin{array}{l}\text { O'Connor }^{54} 2013 \\
\text { (Europe; non-UK) }\end{array}$ & $\begin{array}{l}\text { To explore family physicians' and } \\
\text { practice nurses' perceptions of } \\
\text { barriers and facilitators to the } \\
\text { proposed transfer of diabetes } \\
\text { care to general practice }\end{array}$ & Focus groups & $\begin{array}{l}\text { Practising family physicians and } \\
\text { practice nurses in Limerick city and } \\
\text { county in Ireland }\end{array}$ & $\begin{array}{l}55 \text { family physicians and } 11 \text { practice } \\
\text { nurses }\end{array}$ & General \\
\hline $\begin{array}{l}\text { McHugh }^{55} 2013 \\
\text { (Europe; non-UK) }\end{array}$ & $\begin{array}{l}\text { To examine the barriers to, and } \\
\text { facilitators in, improving diabetes } \\
\text { management from the general } \\
\text { practice perspective }\end{array}$ & Interviews & $\begin{array}{l}\text { Family physicians working in Ireland } \\
\text { who had opted in during a preceding } \\
\text { postal survey on the organisation of } \\
\text { diabetes care }\end{array}$ & 31 family physicians & General \\
\hline
\end{tabular}

